\title{
Peertechz
}

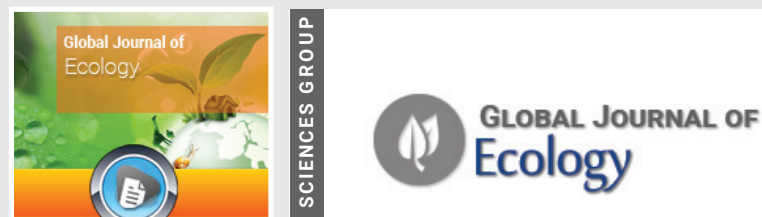

\section{Forest as carbon land for ecological sustainability}

\author{
Abhishek Raj' and MK Jhariya ${ }^{2 *}$ \\ 1Department of Forestry, Mewar University, Chittaurgarh -312901 (Rajasthan), India \\ ${ }^{2}$ Department of Farm Forestry, Sant Gahira Guru Vishwavidyalaya, Sarguja, Ambikapur-497001 (C.G.), \\ India
}

for updates

Received: 19 September, 2020

Accepted: 28 September, 2020

Published: 30 September, 2020

*Corresponding author: MK Jhariya, Department of Farm Forestry, Sant Gahira Guru Vishwavidyalaya, Sarguja, Ambikapur-497001 (C.G.), India,

E-mail: ranger0392@gmail.com

https://www.peertechz.com
Currently 4.70 million ha of forest area lost every year during a decade of 2010-20 which is less than 7.8 million ha $\mathrm{yr}^{-1}$ in the 1990s [1]. The loss of forest areas are also reported as 98 million ha due to fires in the year 2015. Similarly, around 301 million ha $(7.0 \%)$ areas of natural regenerating forest are decreased over the past 30 years [2]. Deforestation contributed approx 20 percent of total green house gas emissions which is more as compared to industrial and transport emissions. Around 2.8 gigaton of carbon removal per year has been observed due to deforestation [3]. Faulty and unsustainable land use practices release gases into the atmosphere and affects overall carbon balance. Burgeoning populations necessitate food and shelter requirement that leads to forest land conversion into cultivable land. This conversion release enormous amount of carbon into the atmosphere resulted global warming. Approx 25.0 percent of total soil organic carbon pools are lost due to anthropogenic and deforestation activity [4]. Therefore, intentional deforestation practices reflects in-depth climate crisis around the world.

Forests as a terrestrial ecosystems work as a carbon sink and represents as biggest "Carbon Land". Forest covered almost 4 billion ha land (30 percent of total earth land areas) consists a huge amount of carbon basically in tropical and boreal regions of S-E Asia and peatlands [5]. Varying life forms exists in the forests that play a key role in biodiversity maintenance and ecosystem processes. Climate change mitigation through carbon sequestration is an intangible form of ecosystem services provided by forest ecosystem [6]. Tropical forest sequesters 0.47-1.3 $\mathrm{Pg} \mathrm{C} \mathrm{yr}^{-1}$ in both vegetations and soils [7]. As per FAO and ITPS [4], approx 1500 Pg carbon has been reported in $1 \mathrm{~m}$ depth of soils. Both tropical and permafrost world comprising high amount of SOC pools in wetlands and peatlands regions [8]. The sequestration of carbon maintains soil organic carbon pools and regulates carbon budget and flux in the forests. Similarly, decaying of forest litters, twig and other residues adds organic matter into the soils that improve carbon and essential nutrient availability for better forest ecosystem (Raj et at. 2020) [9]. However, disturbance and some biotic interference in the forests make imbalance carbon status that can be solve through sustainable forest management practices. Sustainable Forest Management (SFM) improves health and productivity of forests and makes carbon balance and cycling for smoothening functions of ecosystem [10,11]. As per FAO [2] approx. 54 percent (2.05 billion ha) of world forest areas needed for long term management plan. Approx. 18.0 percent (700 million ha) of global forest areas fall legally under protected areas of national parks, game reserves and conservation areas. As per WEF [12] a global initiatives raised for growing, restoring and conserving of almost one trillion trees. In this context, a scientific based forest management practice enhances biodiversity which intensify ecosystem services. One question revolves in my mind "How forest regulates carbon and maintains ecological sustainability?" This question tells lots of story and recall the term "climate change mitigation". Climate resilient forestry maintains ecological sustainability and environmental stability through greater holding of carbon in the form of biomass. Greater carbon absorption helps in climate change mitigation i.e. Climate security and storing carbons as biomass provides some tangible products (timber, fuelwood, fodder and food etc) ensure income security. Thus, recalling the term "Sustainable Management practices (SFM) ensure these significant ecosystem services that maintain overall food-soil-climate security at global scale. Thus, an effective policy and good governance are needed to minimize forest degradations that help in achieving our future forests as carbon land. 


\section{References}

1. FAO and UNEP (2020) The State of the World's Forests 2020. Forests biodiversity and people. Rome. Link: https://bit.ly/3icF5G0

2. FAO (2020) Global Forest Resources Assessment 2020 - Main report. Rome. Link: https://bit.ly/36fzzA8

3. Le Quéré C, Moriarty R, Andrew RM, Canadell JG, et al. (2015) Global carbon budget. Earth System Science Data 7: 349-396. Link: https://bit.ly/30jLDwr

4. FAO and ITPS (2015) Status of the World's Soil Resources, Rome: s.n.

5. Pan Y, Birdsey RA, Phillips OL, Jackson RB (2013) The Structure, Distribution and Biomass of the World's Forests. Annual Review of Ecology, Evolution, and Systematics 44: 593-622. Link: https://bit.ly/3kQuhPA

6. Church J , Clark P, Cazenave A, Gregory J, Jevrejeva S, et al. IPCC (2013) Climate Change 2013: The Physical Science Basis. Contribution of Working Group I to the Fifth Assessment Report of the Intergovernmental Panel on Climate Change. Link: https://bit.ly/349dSz1

7. Mackey B, Kormos CF, Moomaw KH, Houghton WR, Mittermeier RA, et al. (2020) Understanding the importance of primary tropical forest protection as a mitigation strategy. Mitig Adapt Strateg Glob Change . Link: https://bit.ly/2ENOwhG

8. Köchy M, Hiederer R, Freibauer A (2015) Global distribution of soil organic carbon - Part 1: Masses and frequency distributions of SOC stocks for the tropics, permafrost regions, wetlands, and the world. Soil 1: 351-365. Link: https://bit.ly/3n5eNcG

9. Raj A, Jhariya MK, Yadav DK, Banerjee A (2020) Climate Change and Agroforestry Systems: Adaptation and Mitigation Strategies. Apple Academic Press Inc., CRC Press- a Tayler and Francis Group, US \& Canada 383. Link: https://bit.ly/2GfilYK

10. Jhariya MK, Banerjee A, Meena RS, Yadav DK (2019) Sustainable Agriculture, Forest and Environmental Management. Springer Nature Singapore Pte Ltd., 152 Beach Road, \#21-01/04 Gateway East, Singapore 189721, Singapore 606.

11. Banerjee A, Jhariya MK, Yadav DK, Raj A (2020) Environmental and Sustainable Development through Forestry and Other Resources. Apple Academic Press Inc., CRC Press- a Tayler and Francis Group, US \& Canada 400. Link: https://bit.ly/3cK2MEK

12. WEF (2020) One trillion trees - World Economic Forum launches plan to help nature and the climate. In: World Economic Forum [online]. Geneva, Switzerland. Link: https://bit.ly/3kUREYo

\title{
Discover a bigger Impact and Visibility of your article publication with
}

\section{Peertechz Publications}

\author{
Highlights \\ * Signatory publisher of ORCID \\ * Signatory Publisher of DORA (San Francisco Declaration on Research Assessment) \\ * Articles archived in worlds' renowned service providers such as Portico, CNKI, AGRIS, \\ TDNet, Base (Bielefeld University Library), CrossRef, Scilit, J-Gate etc. \\ * Journals indexed in ICMJE, SHERPA/ROMEO, Google Scholar etc. \\ * OAI-PMH (Open Archives Initiative Protocol for Metadata Harvesting) \\ * Dedicated Editorial Board for every journal \\ * Accurate and rapid peer-review process \\ * Increased citations of published articles through promotions \\ * Reduced timeline for article publication \\ Submit your articles and experience a new surge in publication services \\ (https://www.peertechz.com/submission).
}

Peertechz journals wishes everlasting success in your every endeavours

Copyright: @ 2020 Raj A, et al. This is an open-access article distributed under the terms of the Creative Commons Attribution License, which permits unrestricted use distribution, and reproduction in any medium, provided the original author and source are credited. 